ScienceDirect

BIOETHICS UPdate 6 (2020) 121-138
BIOETHICS

UPdate

UNIVERSIDAD

PANAMERICANA

www.elsevier.es/bioethicsupdate

Original article

\title{
Is keeping my child from getting the MMR vaccine unethical? Bioethical arguments for informed decision-making
}

¿Es ético evitar que a mi hijo le apliquen la vacuna triple viral? Argumentos bioéticos para una decisión informada

\author{
Maria O. Valenzuela-Almada*, Benito E. Michel-Izeta, \\ Stéphanie Derive \\ Universidad Panamericana, Mexico City, Mexico \\ Received 8 January 2020; accepted 21 March 2020 \\ Available online 18 June 2020
}

\begin{abstract}
Measles is a viral illness that poses a potentially fatal threat to health all over the world, especially for children. Due to the increase in measles outbreaks in the last few years, and the ever-growing popularity of anti-vaccine groups, it needs to be determined whether or not vaccine refusal is ethical, as it is an important issue that can have an effect on parental decision-making. A brief review is presented on the Measles Mumps Rubella (MMR) vaccine and recent outbreaks, with special attention to the role of anti-vaccine movements. Diverse bioethical perspectives are discussed to answer this issue. Informed consent is advised for all settings and mandatory
\end{abstract}

\footnotetext{
* Corresponding author.

E-mail address: $0171471 @$ up.edu.mx (M.O. Valenzuela-Almada).
} 
vaccination is suggested for high risk children and vulnerable groups, based on the bioethical analysis.

(C) 2020 Centros Culturales de México, A.C. Published by Masson Doyma México S.A. All rights reserved.

Keywords: Measles; MMR; Bioethics; Conscientious objection

\section{Resumen}

El sarampión es una enfermedad viral que amenaza la salud de manera fatal en todo el mundo, en particular a los niños. Debido al reciente incremento en brotes de sarampión, así como a la creciente popularidad de los grupos anti-vacunas, pensamos que es importante determinar si el rechazo a la vacunación es ético, ya que puede tener un efecto en la toma de decisiones de los padres. Se realiza una breve revisión acerca de la vacuna contra sarampión, parotiditis y rubéola, así como de brotes recientes, enfocada en los movimientos anti-vacunas. Se utilizan diferentes corrientes bioéticas para dirimir la cuestión. Se recomienda el uso de consentimiento informado en todas las situaciones y se sugiere la vacunación obligatoria en poblaciones vulnerables de acuerdo al análisis bioético.

(C) 2020 Centros Culturales de México, A.C. Publicado por Masson Doyma México S.A. Todos los derechos reservados.

Palabras clave: Sarampión; Triple viral; Bioética

\section{Introduction}

Vaccination programs around the world are responsible for one of the most efficient preventive medicine strategies ever designed, avoiding potentially lethal diseases in healthy or sick subjects each year. Nevertheless, for as long as they have existed, they have inspired ideological movements against them (Tafuri et al., 2014).

From a bioethical point of view, the exercise of vaccination poses several questions, as it constitutes a preventive intervention applied to a vast number of healthy individuals and, in most cases, to children. Parental misinformation and conscientious objection can play a role in the individual decision to opt out of vaccination (Tafuri et al., 2014). However, vaccines are an inherently social practice, given that the effects of withholding a vaccine from a healthy individual can result in harming entire populations, as is the case of some recent measles outbreaks (Moss, 2017). 
Measles is a highly contagious infection caused by the measles virus, a paramyxovirus of the genus Morbillivirus, which presents with prodromal fever, cough and coryza, followed by a maculopapular rash. Although it can be self-limited up to $40 \%$ of patients can develop complications such as pneumonia. The measles case fatality ratio varies from $0.01 \%$ to $5 \%$ (Rota et al., 2016).

The first measles vaccine was developed in 1963 and since then different preparations of live attenuated vaccines have been created to ensure its safety (McLean, Fiebelkorn, Temte, Wallace, \& Centers for Disease Control and Prevention, 2013). It is currently available in combination with the mumps and rubella viruses (MMR vaccine) and as such it is used in over 90 countries worldwide (Kowalzik, Faber, \& Knuf, 2018). Regarding the potential harms of administering the vaccine, most adverse reactions are rare, aside from local pain in the injection site, and self-limited. These include fever 7-10 days after the first dose $(<15 \%)$, rash $(5 \%)$, lymphadenopathy $(<5 \%)$, thrombocytopenic purpura and parotitis $(<1 \%)(6)$. Although extremely rare, anaphylactic reactions have also been reported (McLean et al., 2013; Meng et al., 2017).

The standard MMR two dose schedule has an effectiveness of $97 \%$ to produce immunity against measles, while the one dose schedule has an effectiveness of $93 \%$ (Uzicanin \& Zimmerman, 2011). As of 2016, 164 countries considered the two dose schedule as part of their routine immunization program, whereas 31 opted for a one dose regimen plus a second dose during vaccination campaigns (Bankamp, Hickman, Icenogle, \& Rota, 2019).

Some vaccines are effective for just specific demographics, such as the rotavirus vaccine in infants or the herpes zoster immunization in adults over 50 years of age. In the case of the MMR vaccine, the group which benefits the most is that of infants and young children; nevertheless as the vaccination coverage in a community increases, other age groups can become more susceptible, such as young adults (Avramovich et al., 2018) and even the elderly (Phadke, Bednarczyk, Salmon, \& Omer, 2016; Rota et al., 2016).

Therefore it is reasonable to conclude that the MMR vaccination provides a substantial benefit in preventing measles which outweighs its harms in severity and duration. It is estimated that $89-94 \%$ of the population should be immune to the measles virus in order to prevent its transmission (Rota et al., 2016). Hence, a high degree of compliance with vaccination is desirable. 
In this article we will discuss the ethical conflict of refusing the MMR vaccine in the light of three bioethical currents: utilitarianism, principlism and personalism.

\section{Epidemiologic background of measles and recent outbreaks}

Ever since the development of the MMR vaccine, the incidence of measles decreased dramatically. In the year 2000 measles was declared eliminated (absence of continuous disease transmission for greater than 12 months) in the United States (Centers for Disease Control and Prevention, 2008), however, since that time several major outbreaks around the world have been recorded.

The most famous ones are the outbreak in Japan in 2007 and the US outbreak in 2008 , in which $91 \%$ of the cases were unvaccinated or had unknown vaccinated status (CDC, 2008). In the European region there was an rise in the number of cases starting in 2011, peaking in 2013, with more than 32,000 cases, about $54 \%$ of which occurred in France (Increased transmission and outbreaks of measles, European Region, 2011, 2011). In 2014 the US had a major outbreak of 383 cases occurring primarily among unvaccinated Amish communities in Ohio imported primarily from the Philippines (Gastañaduy et al., 2016). Furthermore, in 2015 the US had a multi-state outbreak linked to an amusement park. 49 cases were unvaccinated and $28(67 \%)$ had not been vaccinated due to personal beliefs (Zipprich et al., 2015). These cases illustrate the need for a high degree of compliance in vaccination rates in order to protect unvaccinated individuals from infection, in particular in small communities, where vaccinations refusal due to personal beliefs is a major cause of susceptibility.

More recently, the number of outbreaks all over the world is worrying. A total of 17 outbreaks were reported in 2018 alone (CDC, 2018). In 2018 around 328,000 cases were reported to the World Health Organization (WHO), mostly from the European region, with 83,540 measles cases and 74 related deaths (WHO Regional Office for Europe, 2019). Eight countries reported over $88 \%$ of cases, namely Ukraine, Serbia, Israel, France, Italy, Russia, Georgia and Greece. In addition, vaccination coverage is below 95\% in most countries in Europe (WHO, 2018).

Additionally, 372 cases were confirmed in the USA in 2018, more than the double of the cases in 2017 and the greatest number of cases since 2000 (CDC, 2018). As of November 2019, over 413,308 cases have been confirmed. Specifically, 3 outbreaks from imported measles from Israel were recorded in New York and New Jersey among unvaccinated people in Orthodox Jewish communities 
(McDonald et al., 2019). In Mexico a record high number of confirmed cases since 2008 has been reported, all of which have been imported (Comité Nacional Para la Vigilancia Epidemiológica, 2019). Likewise other countries reported increasing cases of measles in 2018 (WHO, 2018).

Even more alarmingly, preliminary data from the WHO shows that cases rose by $300 \%$ percent in the first three months of 2019, in the US only the cases from January to May 2019 surpassed total number of cases in the last 25 years, demonstrating a clear trend (CDC, 2019).

\section{Anti-vaccine movements}

Since the first vaccine was created by Edward Jenner in 1796 and the introduction of compulsory vaccination for smallpox, many anti-vaccine movements have been created along the years; for example the Victorian anti-vaccine movement, the Leicester movement in the 1870s-1880s, the Association of Parents of Vaccine Damaged Children in 1974 in the UK when the DPT vaccine was associated with neurological damage and the polio vaccination boycott by Muslim leaders in Africa, to name a few (Tafuri et al., 2014). However, it was not until 1998, when Andrew Wakefield published his infamous article in The Lancet which linked the MMR vaccine with autism and some forms of colitis that anti-vaccine groups started to gain strength through the internet. Thousands of children were not vaccinated while many scientists tried to refute Wakefield results. In fact, the outbreaks of measles, mumps and rubella in the early 2000s were attributed to those results and measles immunization plummeted from $90 \%$ to $80 \%$ in 2004 in some parts of the world (Dubé, Vivion, \& MacDonald, 2015). Finally, in 2004 new evidence came out suggesting Dr. Wakefield's results were forged, and in 2010 The Lancet removed the article and he was banned from practicing medicine (Murch et al., 2004; Rao \& Andrade, 2011).

Fearsome side effects to immunizations have proven to be powerful reasons to change vaccinations policies. For example, in France in 1998 the vaccination for hep-

atitis $B$ vaccination in teenagers was suspended temporarily because of suspicions of a link between the vaccine and the development of multiple sclerosis, a circumstantial association which was later disproved (Hepatitis B vaccine and multiple sclerosis, 2002). Even though compelling evidence points toward the safety of vaccines, highly publicized events such as these can fuel the anti-vaccine community's plea. 
With the popularization of the internet the anti-vaccination ideas have been spreading more and more. Nowadays people can share links with inaccurate information disguised as "scientific" all around the web (Dubé et al., 2015). As a matter of fact, it has been shown that individuals opposed to vaccination are extremely active on the internet, and that viewing that kind of content increases the risk of negative beliefs regarding immunization (Betsch, Renkewitz, Betsch, \& Ulshöfer, 2010; Pereira et al., 2013).

In an effort to provide reliable information for parents the CDC issued a booklet in 2016 to address the different arguments used by anti-vaccine movements (CDC Parents guide to childhood immunizations, 2016). The most common arguments include that vaccines cause severe illnesses and deaths, that they are a poisonous chemical cocktails, that they are ineffective, that vaccines are not natural, that diseases preventable with vaccines are already eliminated, and that they are a government scheme designed to sterilize the population; among many other religious, economic and political conspiracy theories (Smith, Kennedy, Wooten, Gust, \& Pickering, 2006).

Many of these arguments are made more powerful by the fact that children, the main target population for vaccine application, have diminished autonomy and therefore their parents are in charge of the decision-making process. A number of factors weigh in when analyzing the risks and benefits of a given intervention, these include values, beliefs and estimation of the real risk among others. It has been shown that parents with higher education, economic status, greater trust in health care professionals and more vaccine related information are more likely to perceive that the benefit of childhood vaccination outweighs its risks (Song, 2014).

One would think that as vaccines become safer, thereby eliminating recognized adverse effects, the anti-vaccine groups would lose popularity, nonetheless there has been a recent increase in the phenomenon of vaccination refusal all over the world (Tafuri et al., 2014). Furthermore, the social characteristics of anti-vaccine promoters have changed. In the past the anti-vaccine population consisted of low income people that were against the interventions by the State on the children's body. In comparison, millennial anti-vaccination groups, nowadays labeling themselves as "Pro-safe vaccination" or "Informed decision vaccination" groups to dilute the negative connotations, are well educated people of middle or high income who claim that refusing to vaccinate their children is a personal decision to which they are entitled to after gathering "evidence”(Dubé et al., 2015). 
If these notions are not addressed, doctors can even condone vaccination refusal in order to please the parents. This kind of practice can have deleterious health consequences not only for the child, but for those around him; as illustrated by a recent case report in France in which a primary care physician provided a "vaccine contraindication" certificate to a two year old boy who later proved to be the source of his preterm baby sister's whooping cough (Enfant non vacciné, 2019).

The real impact of anti-vaccine movements is difficult to estimate since it is hard to measure the outreach of these groups. However, there are many examples in the literature that prove the effect of anti-vaccine groups. For example it was demonstrated in Wales in 1997 that an anti-vaccine campaign against MMR vaccine by a local newspaper reduced vaccination uptake by $13.6 \%$ in those areas, a statistically significant difference compared to areas not affected by the publicity, this has also been demonstrated with other vaccines as well (Gangarosa, Galazka, \& Wolfe, 1998; Mason \& Donnelly, 2000).

\section{Vaccine legislation}

Across the globe there are many different approaches regarding vaccination implementation, which vary from recommending them to ensuring mandatory application. No single method can be considered the best, as each one is the result of specific epidemiological, economic and social factors; nevertheless, it is useful to compare them in order to attain a better understanding of the State's interest on the wellbeing of the population.

It is not surprising that following the outbreaks in the European region in 2015, $83 \%$ of which occurred in unvaccinated patients (O'Connor et al., 2017), major changes in vaccination policies took place. Even though $94 \%$ of the European countries ensure the public financing of immunization services only about half of them have mandatory immunization programs (Sabin Vaccine Institute, 2018). The methods for ensuring the vaccination coverage in these countries include imposing penalties for refusing them and requiring them to enter schools. Penalties can range from monetary fines to criminal charges for negligence. As an example, in France mandatory MMR vaccination is ensured through nurseries and schools, where access is denied for unimmunized children without a medical contraindication, and parents could even be charged with voluntary deprivation of care, a criminal offense punished with 7 years in prison and a 100,000 euro fine (Code Pénale Francais, 1992). Such a penalty represents a powerful incentive to vaccinate one's children, and as 
such it aims to reduce vaccination refusal for nonmedical reasons. According to the WHO the estimated coverage for the first dose of MMR is 90\% in France (WHO, 2019).

However, it is noteworthy that in the European region the highest immunization coverage rates are not only achieved in countries with mandatory vaccination, such as Belgium, France and Hungary, but also in those with no mandatory or enforcement provisions, such as Lithuania, Finland and the United Kingdom (Sabin Vaccine Institute, 2018). In Lithuania for example even though the MMR vaccine is provided by the government at no cost to the patient, there are no mandatory vaccines and no monitoring system exists to detect unvaccinated children, and the estimated MMR coverage for the first dose is $94 \%$ (WHO, 2019).

Moreover, vaccination legislation in Latin America also relies heavily on mandatory vaccinations, with over $92 \%$ of the population living in countries with compulsory vaccination laws, mostly based on the perception of vaccines as a public good provided free of charge by the government (Trumbo et al., 2013). In Mexico where MMR vaccination is mandatory and there are no penalties for parents who refuse immunization of their children (Ley General de Salud, 2019), the MMR first dose coverage rate is $96 \%$ (WHO, 2019).

The United States of America have a similar policy, where immunizations are required in order to attend schools (Lindley, Horlick, Shefer, Shaw, \& Gorji, 2007), even though each state allows for different types of exemptions. All of them consider medical exemptions (medical contraindications) and the vast majority also considers religious exemptions, which can certainly fall under conscientious objection, but there are currently 15 states that consider "philosophical" exemptions (Salmon et al., 2005), an ill-defined term that can encompass numerous spurious reasons for opting out of vaccinations. The coverage rate for the MMR first dose in the United States of America is $92 \%$ (WHO, 2019).

Therefore, it is evident that while instituting mandatory immunization laws is an effective way to maintain a safe coverage rate, it is by no means the only one.

\section{The bioethical point of view}

It is easy to detect several bioethical conflicts regarding vaccination. Most bioethical problems have complex solutions which are often limited to the individual case in 
Table 1

Summary of the arguments proposed by three different bioethical perspectives regarding MMR vaccination.

\begin{tabular}{|c|c|}
\hline $\begin{array}{l}\text { Bioethical } \\
\text { perspectives }\end{array}$ & Key arguments \\
\hline Utilitarianism & $\begin{array}{l}\text { - Since measles vaccination aims for the greatest good for the population and not for an } \\
\text { individual, everyone without medical contraindications should receive it. } \\
\text { - The fact that measles vaccination is cost-effective supports obligatory measles } \\
\text { vaccination. }\end{array}$ \\
\hline Principlism & $\begin{array}{l}\text { - Based on the autonomy principle, the parents can exercise their refusal only after } \\
\text { considering the known risks and benefits of the vaccine. } \\
\text { - Misinformation makes informed decision making impossible and diminishes } \\
\text { autonomy. } \\
\text { - The beneficence and nonmaleficence principles imply that measles vaccination is } \\
\text { justified since the benefit of the vaccine outweighs its risks. } \\
\text { - The justice principle implies that it is important to make vaccination available globally } \\
\text { and to create equally accessible programs for the surveillance and management for } \\
\text { adverse events following vaccination. }\end{array}$ \\
\hline Personalism & $\begin{array}{l}\text { - Interventions that produce or maintain health are regarded as correct. As the MMR } \\
\text { vaccine prevents deterioration of health, opposing its application, without medical } \\
\text { contraindications, can be regarded as misconduct. } \\
\text { - Freedom is limited by the defense of life and one is morally obligated to collaborate in } \\
\text { preserving one's health. Therefore, health can be endangered due to conscientious } \\
\text { objection against measles vaccination. }\end{array}$ \\
\hline
\end{tabular}

which they arise. First we will analyze whether opting out of MMR vaccination is ethically wrong in the light of three different bioethical perspectives: utilitarianism, principlism, and personalism. We believe each one of these perspectives proposes useful arguments in order to solve the ethical conflict, summarized in Table 1.

From the utilitarianism point of view, a bioethical current created in XVIII century by Jeremy Bentham in England, the correct choice in a given case is the one that will produce the greatest good for the greatest number of individuals.

The MMR vaccine reduces the suffering of the affected children (that of their parents, of course) and in some cases that of adults. Moreover, defendants of utilitarianism advocate for cost-effectiveness of interventions. Measles vaccination cost-effectiveness has been proven in multiple studies in many countries (Doshi et al., 2017). As an example, the net yearly cost of the MMR vaccination program, including indirect costs such as missed parental productivity was estimated to be around $303,000,000$ USD whereas the annual cost related to measles infection would be around $\$ 5,000,000,000$ USD if no vaccination program existed (Zhou et al., 2004). 
Thanks to the immunization program it is estimated that around $\$ 7,000,000,000$ USD are saved each year (Zhou et al., 2004), and said savings are beneficial to the whole of society, because they can be used for the betterment of a multitude of issues, instead of being spent in treating this illness.

It follows that the MMR vaccination could be made obligatory because it prevents serious illness in most of those vaccinated, and only rarely produces serious or lasting side effects. Therefore, everyone who does not have a medical contraindication for a vaccine should receive it, as it prevents measles infection in the unvaccinated minority and in themselves. People with medical contraindications and those who conscientiously object to MMR vaccination should remain exempt from the vaccine given that, if a high coverage rate is accomplished in their communities, they would effectively be protected against measles, at no extra cost, and with less suffering than if they received the vaccine.

Using this straightforward thinking it is clear to see that opting out of the MMR vaccine is a wrong choice, given that it can cause suffering to oneself and to others, and entails only personal satisfaction as a benefit. Nevertheless, such a rigorous approach can forego personal liberties easily and could endanger the life of the unvaccinated individuals.

Now, according to principlism, established in the Belmont report in 1974 and reformulated by Beauchamp and Childress in 1979, there are four principles that must be taken into consideration for a moral decision-making approach including autonomy (based on the value of freedom), non maleficence (based on the value of integrity), beneficence (based on the value of goodness) and justice (based on the value of justice) (Beauchamp \& Childress, 2001). Even though this approach is widely used when debating ethical conflicts, it is worth noting that its original scope was to classify the indispensable principles to respect in order to carry out medical experiments on human subjects. When it comes to vaccination the most debated principles are autonomy and justice, that often enter in conflict with the no maleficence and beneficence principles. The latter principles are strongly supported by the known benefits and harms of the MMR vaccine, given that the standard 2 dose schedule provides effectiveness of $97 \%$ to produce immunity against a highly contagious disease than can kill up to $5 \%$ of those who acquire it, whereas the adverse reactions associated with the administration of the vaccine are uncommon and only rarely serious. It is also worth mentioning that the other components of the vaccine, the mumps and rubella viruses provide protection against mumps and rubella at no 
extra risk. This adds to the benefits of the MMR vaccine, given that the side effects reported are those of the whole vaccine, not only the measles attenuated virus.

Autonomy, on the one hand, can be thought of as the right of the parent to choose for his or her child. This principle is questioned when that decision increases the risk of a potentially fatal disease in the individual and in the community as a whole. Since children aged 1 and 6 years cannot exercise their right of autonomy due to their limited ability to make medical decisions - a condition referred to as lack of capacity - a qualified person needs to make such decisions for them, as the patient's surrogate (Hickey \& Lyckholm, 2004). Most often the designated adults are the patient's parents, who have the ethical and moral responsibility to take well informed decisions based on their children's best interests, not on their own wishes.

Therefore there are restrictions applied to the autonomy principle when the decisions of the parent do not benefit or even harm the patient. For example a parent may deny a lifesaving treatment for himself but he/she cannot deny it for his/her children and an ethics committee or a court would have to intervene. However since vaccination is not done in an emergency setting or as a lifesaving procedure, the ethics conflict around the conscientious objection from the parents is harder to solve.

The respect for the autonomy principle and vaccination has been discussed by Asveld in detail, stating that autonomy is not only the right to make choices but the right to make the "good" choices, concluding that if the person has a valid and sincere claim within a given social context then it would be acceptable to refuse vaccination (Asveld, 2008).

For example, it would be correct for a parent to refuse MMR vaccination if his or her child were allergic to it. Nonetheless, the right course of action becomes less clear when religious, moral or philosophical objections arise. If a parent sincerely believes that vaccines are inherently dangerous, he might believe the right choice is to refuse them. In this example, parental beliefs, regardless of their sincerity, are based on false information and they can therefore lead to wrong conclusions. Their autonomy is reduced because their decision-making process is biased and they are unable to consider the options in their true light. Hence, correct information about the benefits and risks of the vaccine is a necessary condition that must be attained in order to fully exercise autonomy.

Clarke et al. considers the issue of conscientious objection to vaccination based on religious, moral or philosophical convictions, concluding that conscientious 
objectors for vaccination must provide enough evidence that supports their objection as well as provide a commensurate contribution to society in order for them to be discharged of a duty that contributes to the public good. They suggest a financial contribution to the state proportional to the estimate cost of risks caused by not being vaccinated (Clarke, Giubilini, \& Walker, 2017). This suggestion could be considered as a utilitarian approach as well.

Justice, on the other hand, represents the fair distribution between benefits and burdens. In the context of vaccination, it applies for different issues. The first is the fact that vaccination should be equally accessible for everyone. All of the member states of the UN have included at least one dose of a measles virus containing vaccine (MVC) in their vaccination schedule, therefore access to the vaccine is justly distributed, but coverage is not equally attainable (Burton et al., 2009). In the latest WHO and UNICEF report, the global coverage for one dose of MVC vaccine was $85 \%$, whereas coverage for a second dose (included in $86 \%$ of the countries) was only 67\% (VanderEnde, Gacic-Dobo, Diallo, Conklin, \& Wallace, 2018).

Another issue when considering the justice principle is the next question: why should a given population "suffer" the burden of vaccination in exchange for the benefits of another population? Taking into account that the potential adverse effects of the MMR vaccine are known, the benefits for the community outweigh the harms of the vaccinated individual. To further minimize the "burden", as it is suggested by Castro Lessa, a solution consists on the creation of equally accessible programs for the surveillance and management for adverse events following vaccination (Castro, 2013). Moreover, the population that benefits from herd immunity is often in a vulnerable situation, as they cannot receive proper immunizations because of young age, severe immunosuppression, allergy, major illness, or pregnancy. Being unable to attain active immunity in a safe way (through vaccination), they rely heavily on low disease prevalence to avoid infection. So, in terms of justice it would also be unfair that vulnerable people who cannot be vaccinated suffer the consequences of low vaccine coverage in healthier individuals.

With these four principles in mind, in the case of MMR vaccination, beneficence, no maleficence and justice support the correctness of MMR vaccination and the incorrectness of withholding it in those who have no contraindications. However, the autonomy principle supports the withholding of vaccination for those who conscientiously object to it, given that they possess the necessary means to make an informed decision. The principlism approach reaches an impasse whenever parents object to vaccination of their children on the basis of an informed decision. 
In comparison, the personalist current of bioethics, which was proposed by Emmanuel Mounier in France, in the 20th century, addresses this issue in a different way. Personalism was an intellectual movement inaugurated under this denomination by Mounier and later developed by a variety of philosophers in different countries. Its central view consists in the conception of the human being as a "person", that is, as an individual being consisting of two distinct but inseparable components: one material (the body) and one spiritual (the soul). Every person has also a communitarian dimension because is related to other persons and open to an interchange with them, contributing in such a way to the life of society. As in the case of principialism, the best-known elaboration of personalism in the domain of bioethics is represented by a treatise (Sgreccia, 2003).

Personalism also relies on principles to unravel dilemmas, namely these are: the defense of the person's physical life, freedom and responsibility, the therapeutic principle and the sociality and subsidiarity principle (Sgreccia, 2003).

The first and the third principles are the basis for medical interventions. Because health is desirable in order to maintain our physical bodies, interventions that produce or maintain health are regarded as correct. As the MMR vaccine prevents deterioration of health, opposing its application can be regarded as misconduct, nevertheless, when the reasons for choosing skipping a vaccine are related to medical contraindications (compromised immunity, severe illness, allergy), health is being preserved. Other reasons that invoke these principles are the fear of adverse reactions, which must be reviewed through informed consent in order to prevent misinformation. As we have reviewed, adverse reactions related to MMR vaccine are for the most part negligible, whereas the benefit it provides is of proven value, therefore it is our belief that the objection to consent cannot logically derive from fear of individual harm.

The therapeutic principle states that when no other alternatives exist, an action which damages a part of the body can be undertaken only if this is the mean to avoid damaging the rest of the body or endanger the person's life. Harm to a part of the body can be thought of as pain in the injection site and some rare adverse events like rash or thrombocytopenia, yet their transient nature evidently outweigh a potentially lethal disease.

Addressing the freedom and responsibility principle can be similar to the autonomy principle, yet the personalist approach concedes that freedom is limited by the defense of life and that one is morally obligated to collaborate in preserving one's health. How can conscientious objection be defended in the light of this principle? 
The personalist approach recognizes that humans possess two fundamental principles, the body and the soul, and neither one can sustain by itself the existence of the individual; therefore, both must be protected and allowed to thrive. On the one side, objecting to the administration of the MMR vaccine to one's children does not cause physical harm in itself, but it endangers their body's health and that of those around him in the immediate future. Even though the vaccine administration can cause physical damage, transient as it may be, the lifelong health benefits clearly outweigh the risks to the body. The soul, on the other side, can be damaged when a sincere and conscientious objection is denied and the vaccine is administered. In said case, the will to protect one's soul endangers the will to protect one's body.

Conscientious objection to MMR vaccination could occur under religious, moral or philosophical motives. Given that the MMR vaccine is derived from chick embryo tissue, Buddhists might object to its application, because it comes from a living being, or orthodox protestants might claim that preventing a potentially deadly disease interferes with the divine providence (Dubé et al., 2015).

The commutable nature of the disease at hand is a key factor in deciding what action to take. The risk of the physical body can be determined to be higher than that of the soul, even when objection to the vaccine is based on solid arguments and not untrustworthy misinformation. When the vaccine compliance rate in a given community is low enough, the risk of an outbreak becomes greater for the community as a whole, thereby increasing the chances of fatal outcomes, especially in those individuals who cannot receive the MMR vaccine because of medical contraindications. Risking one's life and that of others directly violates the four personalist principles, and can therefore be considered an unethical action. As the individual has an obligation to contribute to social well-being, it is the risk of contracting the disease and infecting others that allows for the application of the MMR vaccine even in the context of conscientious objection, in specific settings.

Based on the previous arguments, we believe the recommendation of vaccination depends on the current risk of infection. If the risk of infection were found to be low, (when over $94 \%$ of the population has received the vaccine), said conscientious objections would have to be accepted, as the damage to the soul would be judged to be greater than that to the body. Nevertheless, in the setting of an outbreak, or with a low vaccination coverage in the community, the probability of getting and spreading measles to other children should overcome the moral, philosophical or religious harm based on the principle of subsidiarity (the moral obligation to contribute to social well-being), preserving the individual's health and considering these to be extreme 
circumstances, in order to allow for an involuntary wrongdoing in the process of a good action.

\section{Conclusions: what would be the right thing to do as a parent?}

As physicians it is our duty to educate, advise, guide and counsel patients, both at the bedside and at a community level. Therefore, it must be stated that the MMR vaccine poses negligible, transient and infrequent medical risks, whereas the health benefits it offers are time-tested, long lasting and lifesaving, to both the children and those around them. Parents must be able to receive up to date information regarding the state of measles outbreaks and community vaccination rates, not only national coverage rates, which they can translate into personal risks for their children, as well as evidence-based advice on adverse reactions and contraindications. Their doubts and fears must be met with patience and confidence founded on scientific knowledge.

As children have diminished autonomy, their parents are responsible for the consent or objection to any medical procedure. When pondering the alternatives, it is imperative to consider the children's well-being as opposed to one's self. It is our belief that the information we have provided in this article can help physicians better guide parents in making these decisions.

Both principlism and personalism agree that the freedom and autonomy of an individual must be respected, however personalist approach establishes a limit to personal freedom, when it goes against the individual's health. Furthermore, utilitarianism looks for the greatest good for the community.

Therefore, we believe that, given the high degree of vaccination compliance needed in order to attain herd immunity, the answer to our title question depends on the community's vaccination coverage. It is our advice for primary care physicians to inform parents of the known risks and benefits of the MMR vaccine and to obtain informed consent. In the setting of conscientious objection it would be acceptable to apply mandatory MMR immunization to all children without medical contraindications if there is a local outbreak or if the population immunization coverage is less than ideal, as long as informed consent was attempted and the local immunization rate is known to be below 89-94\% threshold. Both conditions should be registered on the clinical record. Only in settings of low risk of outbreaks would conscientious objection outweigh the need to vaccinate a child. 


\section{Conflicts of interest}

The authors have none declarations of interest.

\section{References}

Asveld, L. (2008). Mass-vaccination programmes and the value of respect for autonomy. Bioethics, 22(5), 245-257. http://dx.doi.org/10.1111/j.1467-8519.2008.00630.x

Avramovich, E., Indenbaum, V., Haber, M., Amitai, Z., Tsifanski, E., Farjun, S., et al. (2018). Measles outbreak in a highly vaccinated population - Israel, July-August 2017. MMWR - Morbidity and Mortality Weekly Report, 67(42), 1186-1188. http://dx.doi.org/10.15585/mmwr.mm6742a4

Bankamp, B., Hickman, C., Icenogle, J. P., \& Rota, P. A. (2019). Successes and challenges for preventing measles, mumps and rubella by vaccination. Current Opinion in Virology, 34, 110-116. http://dx.doi.org/10.1016/j.coviro.2019.01.002

Beauchamp, T. L., \& Childress, J. F. (2001). Principles of biomedical ethics (5th edition). Oxford, England: Oxford University Press.

Betsch, C., Renkewitz, F., Betsch, T., \& Ulshöfer, C. (2010). The influence of vaccine-critical websites on perceiving vaccination risks. Journal of Health Psychology, 15(3), 446-455. http://dx.doi.org/10.1177/1359105309353647

Burton, A., Monasch, R., Lautenbach, B., Gacic-Dobo, M., Neill, M., Karimov, R., et al. (2009). WHO and UNICEF estimates of national infant immunization coverage: Methods and processes. Bulletin of the World Health Organization, 87(7), 535-541. http://dx.doi.org/10.2471/blt.08.053819

Castro, L. (2013). Bioethics and mass childhood vaccination. Revista Bioética, 21(2), 225-235.

Centers for Disease Control Prevention (CDC). (2008). Update: Measles - United States, January-July 2008. MMWR - Morbidity and Mortality Weekly Report, 57(33), 893-896. Retrieved from: https://www.cdc.gov/mmwr/preview/mmwrhtml/mm5733a1.htm

Centers for Disease Control Prevention. (2018). Measles outbreaks.. Retrievevd from https://www.cdc.gov/measles/cases-outbreaks.html

Centers for Disease Control Prevention. (2019). U.S. measles cases in first five months of 2019 surpass total cases per year for past 25 years [Press release].. Retrieved from: https://www.cdc.gov/media/releases/2019/p0530-us-measles-2019.html (30.05.19)

(2016). Centers for Disease Control and Prevention: Parents Guide to Childhood Immunizations.. Retrieved from: https://www.cdc.gov/vaccines/parents/tools/parents-guide/index.html

Clarke, S., Giubilini, A., \& Walker, M. J. (2017). Conscientious objection to vaccination. Bioethics, 31(3), 155-161. http://dx.doi.org/10.1111/bioe.12326

Code Pénale Francais. (1992). Loi $n^{\circ} 92-684$ du 22 juillet 1992 portant réforme des dispositions du code pénal relatives à la répression des crimes et délits contre les personnes. Article 227-15.. Retrieved from: https://www.legifrance.gouv.fr/affichTexte.do?cidTexte=JORFTEXT000000540288\&categorieLien=id

Comité Nacional Para la Vigilancia Epidemiológica. (2019). Aviso Epidemiológico. Situación Epidemiológica del Sarampión. México.. Retrieved from: https://www.gob.mx/cms/uploads/attachment/file/438120/AE-Sarampion-15022019.pdf

Doshi, R. H., Eckhoff, P., Cheng, A., Hoff, N. A., Mukadi, P., Shidi, C., et al. (2017). Assessing the costeffectiveness of different measles vaccination strategies for children in the Democratic Republic of Congo. Vaccine, 35(45), 6187-6194. http://dx.doi.org/10.1016/j.vaccine.2017.09.038

Dubé, E., Vivion, M., \& MacDonald, N. E. (2015). Vaccine hesitancy, vaccine refusal and the antivaccine movement: Influence, impact and implications. Expert Review of Vaccines, 14(1), 99-117. http://dx.doi.org/10.1586/14760584.2015.964212 
Enfant non vacciné: un médecin d'Angers suspendu. (2019). Le Parisien.. Retrieved from: http://www.leparisien.fr/societe/enfant-non-vaccine-un-medecin-d-angers-suspendu-03-01-2019-7980438. php $\% 0 \mathrm{~A}$

Gangarosa, E. J., Galazka, A. M., Wolfe, C. R., Phillips, L. M., Gangarosa, R. E., Miller, E., et al. (1998). Impact of anti-vaccine movements on pertussis control: The untold story. Lancet, 351(9099), 356-361. http://dx.doi.org/10.1016/s0140-6736(97)04334-1

Gastañaduy, P. A., Budd, J., Fisher, N., Redd, S. B., Fletcher, J., Miller, J., et al. (2016). A measles outbreak in an underimmunized amish community in Ohio. The New England Journal of Medicine, 375(14), 1343-1354. http://dx.doi.org/10.1056/NEJMoa1602295

(2002). Hepatitis B vaccine and multiple sclerosis. Weekly Epidemiological Record, 47(77), 389-404. Retrieved from: https://www.who.int/docstore/wer/pdf/2002/wer7747.pdf

Hickey, K. S., \& Lyckholm, L. (2004). Child welfare versus parental autonomy: Medical ethics, the law, and faith-based healing. Theoretical Medicine and Bioethics, 25(4), 265-276. http://dx.doi.org/10.1007/s11017-004-3137-7

(2011). Increased transmission outbreaks of measles, European Region, 2011. Releve Epidemiologique Hebdomadaire, 86(49), 559-564. Retrieved from: https://www.who.int/wer/2011/wer8649.pdf?ua=1

Kowalzik, F., Faber, J., \& Knuf, M. (2018). MMR and MMRV vaccines. Vaccine, 36(36), 5402-5407. http://dx.doi.org/10.1016/j.vaccine.2017.07.051

Ley General de Salud Mexicana. (2019). Capítulo 2 bis.. Retrieved from: http://www.salud.gob.mx/cnts/pdfs/LEY_GENERAL_DE_SALUD.pdf

Lindley, M. C., Horlick, G. A., Shefer, A. M., Shaw, F. E., \& Gorji, M. (2007). Assessing state immunization requirements for healthcare workers and patients. American Journal of Preventive Medicine, 32(6), 459-465. http://dx.doi.org/10.1016/j.amepre.2007.02.009

Mason, B. W., \& Donnelly, P. D. (2000). Impact of a local newspaper campaign on the uptake of the measles mumps and rubella vaccine. Journal of Epidemiology and Community Health, 54(6), 473-474. http://dx.doi.org/10.1136/jech.54.6.473

McDonald, R., Ruppert, P. S., Suoto, M., Johns, D. E., McKay, K., Bessette, N., et al. (2019). Measles outbreaks from imported cases in orthodox jewish communities - New York and New Jersey, 2018-2019. Morbidity and Mortality Weekly Report, 68(19), 444-445. Retrieved from: https://www.cdc.gov/mmwr/volumes/68/wr/pdfs/mm6819a4-H.pdf

McLean, H. Q., Fiebelkorn, A. P., Temte, J. L., Wallace, G. S., \& Centers for Disease Control and Prevention. (2013). Prevention of measles, rubella, congenital rubella syndrome, and mumps, 2013: Summary recommendations of the Advisory Committee on Immunization Practices (ACIP). Recommendations and reports. MMWR - Morbidity and Mortality Weekly Report, 62(RR-04), 1-34. Retrieved from: https://www.cdc.gov/mmwr/preview/mmwrhtml/rr6204a1.htm

Meng, F. Y., Sun, Y., Shen, Y. G., Pan, H. F., Tang, J. H., Wang, B. B., et al. (2017). Safety of measlescontaining vaccines in post-marketing surveillance in Anhui, China. PLOS ONE, 12(2), e0172108. http://dx.doi.org/10.1371/journal.pone.0172108

Moss, W. J. (2017). Measles. Lancet (London, England), 390(10111), 2490-2502. http://dx.doi.org/10.1016/S0140-6736(17)31463-0

Murch, S. H., Anthony, A., Casson, D. H., Malik, M., Berelowitz, M., Dhillon, A. P., et al. (2004). Retraction of an interpretation. Lancet (London, England), 363(9411), 750. http://dx.doi.org/10.1016/S0140-6736(04)15715-2

O’Connor, P., Jankovic, D., Muscat, M., Ben-Mamou, M., Reef, S., Papania, M., et al. (2017). Measles and rubella elimination in the WHO Region for Europe: Progress and challenges. Clinical Microbiology and Infection, 23(8), 504-510. http://dx.doi.org/10.1016/j.cmi.2017.01.003

Phadke, V. K., Bednarczyk, R. A., Salmon, D. A., \& Omer, S. B. (2016). Association between vaccine refusal and vaccine-preventable diseases in the United States: A review of measles and pertussis. JAMA, 315(11), 1149-1158. http://dx.doi.org/10.1001/jama.2016.1353 
Pereira, J. A., Quach, S., Dao, H. H., Kwong, J. C., Deeks, S. L., Crowcroft, N. S., et al. (2013). Contagious comments: What was the online buzz about the 2011 Quebec measles outbreak? PLOS ONE, 8(5), e64072. http://dx.doi.org/10.1371/journal.pone.0064072

Rao, T. S., \& Andrade, C. (2011). The MMR vaccine and autism: Sensation, refutation, retraction, and fraud. Indian Journal of Psychiatry, 53(2), 95-96. http://dx.doi.org/10.4103/0019-5545.82529

Rota, P. A., Moss, W. J., Takeda, M., de Swart, R. L., Thompson, K. M., \& Goodson, J. L. (2016). Measles. Nature Reviews. Disease Primers, 2, 16049. http://dx.doi.org/10.1038/nrdp.2016.49

Sabin Vaccine Institute. (2018). Legislative landscape review: Legislative approaches to immunization across the European Region.. Retrieved from: https://www.sabin.org/ sites/sabin.org/files/legislative_approaches_to_immunization_europe_sabin_0.pdf\%0A

Salmon, D. A., Sapsin, J. W., Teret, S., Jacobs, R. F., Thompson, J. W., Ryan, K., et al. (2005). Public health and the politics of school immunization requirements. American Journal of Public Health, 95(5), 778-783. http://dx.doi.org/10.2105/AJPH.2004.046193

Sgreccia, E. (2003). Manuale di Bioetica. Milano, Italy: Vita e Pensiero.

Smith, P. J., Kennedy, A. M., Wooten, K., Gust, D. A., \& Pickering, L. K. (2006). Association between health care providers' influence on parents who have concerns about vaccine safety and vaccination coverage. Pediatrics, 118(5), e1287-e1292. http://dx.doi.org/10.1542/peds.2006-0923

Song, G. (2014). Understanding public perceptions of benefits and risks of childhood vaccinations in the United States. Risk Analysis, 34(3), 541-555. http://dx.doi.org/10.1111/risa.12114

Tafuri, S., Gallone, M. S., Cappelli, M. G., Martinelli, D., Prato, R., \& Germinario, C. (2014). Addressing the anti-vaccination movement and the role of HCWs. Vaccine, 32(38), 4860-4865. http://dx.doi.org/10.1016/j.vaccine.2013.11.006

Trumbo, S. P., Janusz, C. B., Jauregui, B., McQuestion, M., Felix, G., Ruiz-Matus, C., et al. (2013). Vaccination legislation in Latin America and the Caribbean. Journal of Public Health Policy, 34(1), 82-99. http://dx.doi.org/10.1057/jphp.2012.66

Uzicanin, A., \& Zimmerman, L. (2011). Field effectiveness of live attenuated measles-containing vaccines: A review of published literature. The Journal of Infectious Diseases, 204(Suppl. 1), S133-S148. http://dx.doi.org/10.1093/infdis/jir102

VanderEnde, K., Gacic-Dobo, M., Diallo, M. S., Conklin, L. M., \& Wallace, A. S. (2018). Global Routine Vaccination Coverage - 2017. MMWR - Morbidity and Mortality Weekly Report, 67(45), 1261-1264. http://dx.doi.org/10.15585/mmwr.mm6745a2

World Health Organization. (November 2018). Global measles and rubella update.. Retrieved from: https://www.who.int/immunization/monitoring_surveillance/burden/vpd/surveillance_type/active/Global_ MR_Update_November_2018.pdf?ua=1

World Health Organization. (2019). WHO vaccine-preventable diseases: Monitoring system 2019 global summary. Retrieved from: http://apps.who.int/ immunization_monitoring/globalsummary/countries?countrycriteria\%5Bcountry\%5D $\% 5 \mathrm{~B} \% 5 \mathrm{D}=\mathrm{FRA}$

World Health Organization Regional Office for Europe. (2019). WHO EpiBrief, No. 2/2019: A report on the epidemiology of selected vaccine-preventable diseases in the European Region.. Retrieved from: http://www.euro.who.int/_data/assets/pdf_file/0017/410714/EpiBrief_2_2019_EN.pdf?ua=1

Zhou, F., Reef, S., Massoudi, M., Papania, M. J., Yusuf, H. R., Bardenheier, B., et al. (2004). An economic analysis of the current universal 2-dose measles-mumps-rubella vaccination program in the United States. The Journal of Infectious Diseases, 189(Suppl. 1), S131-S145. http://dx.doi.org/10.1086/378987

Zipprich, J., Winter, K., Hacker, J., Xia, D., Watt, J., Harriman, K., et al. (2015). Measles outbreak - California, December 2014-February 2015. MMWR - Morbidity and Mortality Weekly Report, 64(6), 153-154. Retrieved from: https://www.cdc.gov/mmwr/preview/mmwrhtml/mm6406a5.htm 